\title{
Effect of Homogenization on the Superplasticity and Microsuperplasticity of the Al-Zn-Mg-Cu Aluminum Alloy
}

\author{
V.V. Bryukhovetsky ${ }^{1, *}$, D.E. Myla1,2, V.P. Poyda ${ }^{2}$, A.V. Poyda ${ }^{1}$ \\ ${ }^{1}$ Institute of Electrophysics and Radiation Technologies NAS of Ukraine, PO box 8812, 28, Chernyshevskiy St., \\ 61002 Kharkiv, Ukraine \\ ${ }^{2}$ V.N. Karazin Kharkiv National University, 4, Svobody Sq., 61000 Kharkiv, Ukraine
}

(Received 03 September 2020; revised manuscript received 18 December 2020; published online 25 December 2020)

\begin{abstract}
The article discusses the effect of preliminary high-temperature homogenization annealing on the microstructural changes in alloy 1933 and their correlation with the superplasticity and microsuperplasticity of the alloy. The research shows that annealing of alloy 1933 at $520^{\circ} \mathrm{C}$ for $2 \mathrm{~h}$ leads to the dissolution and melting of the $\eta$-phase particles $\left(\mathrm{MgZn}_{2}\right)$, T-phase particles $\left(\mathrm{Mg}_{3} \mathrm{Zn}_{3} \mathrm{Al}_{2}\right)$, and S-phase particles $\left(\mathrm{Al}_{2} \mathrm{CuMg}\right)$, which are present in the initial microstructure of the alloy. The annealing results in a redistribution of the crystallographic orientations of the crystallites of the $\alpha$-solid solution based on aluminum and the removal of internal microstresses in the volume of the alloy. It is found that preliminary heat treatment slightly affects the mechanical behavior of alloy 1933 under conditions of superplastic deformation. Fibrous structures, the process of the formation and development of which is called microsuperplasticity, are observed both in the samples that have not undergone preliminary homogenization annealing and in the annealed samples. The concentration of $\mathrm{Mg}$ atoms in the fibers is higher than their average concentration in the alloy. At the same time, the concentration of $\mathrm{Zn}$ and $\mathrm{Cu}$ atoms in the fibers is almost two times lower than their concentration in the alloy. The authors propose the mechanism of fiber formation and development, where fiber nucleation is caused by viscous flow of the material formed by melting of $\alpha$-magnesium enriched solid solution based on alumina, and further fiber growth is carried out by the complex of deformation mechanisms operating during the superplastic flow of the alloy.
\end{abstract}

Keywords: Aluminum alloy, Homogenization, Mechanisms of the formation of fibrous structures, Microsuperplasticity, Superplasticity.

DOI: $10.21272 /$ jnep.12(6).06025

PACS numbers: 62.20.Fe, 62.20.Hg

\section{INTRODUCTION}

Chemical and phase compositions of aluminumbased alloys have a significant impact on their structure and properties deformed under conditions of superplasticity [1]. The phase composition primarily affects the microstructure stability during superplastic deformation. Structure type, area, and relative fraction of intergrain and interphase boundaries in the alloy microstructure depend on its phase composition. Features of the development of mechanisms of deformation, pore formation, and fracture are also mainly determined by the phase composition of the material, the deformation characteristics of the phases and their morphology. The phase and chemical compositions of the alloys have a significant effect on the implementation of processes that lead to the formation of impurity atom segregations and foci of the liquid phase at interphase boundaries during the deformation of samples under conditions of superplasticity at high homological temperatures. Therefore, the study of structural changes and phase transformations caused by heat treatment is an important aspect of studying the effect of superplasticity.

During superplastic deformation, the material undergoes several structural changes that are currently being extensively studied and justified [1]. However, the question of the mechanism of nucleation and development of fibrous structures during superplastic deformation remains debatable [2-8]. Fibers were found in surface pores and cracks, as well as on the fracture sur- faces of samples deformed under conditions of superplasticity. The process of the formation of fibrous structures during superplastic deformation is called "microsuperplasticity" [2-4]. According to [2], microsuperplasticity is a superplastic deformation carried out at the microscopic level, which leads to fiber formation. Sources [2-8] considered and discussed several mechanisms of the formation and development of fibrous structures. However, all the mechanisms of fiber formation discussed in the literature cannot fully explain either their origin or their morphological differences [8].

Since the formation and development of fibrous structures is one of the characteristic structural changes that occur during superplastic deformation, it seems appropriate to study the effect of homogenization annealing on the process of fiber formation. Such studies were conducted in several works [3, 5, 8]. Their authors carried out homogenization annealing at high homological temperatures, which provide fast solubility of the intermetallic phases. For instance, in [5], preliminary homogenization annealing of the samples of aluminum alloy AA7475 was carried out at $516^{\circ} \mathrm{C}$ for 2 to $8 \mathrm{~h}$. The same temperature was optimal for the manifestation of superplasticity by the samples of this alloy that did not undergo homogenization annealing. The authors of [5] concluded that preliminary heat treatment increases the resistance of the samples of alloy AA7475 to pore formation during superplastic deformation. This is caused by a decrease in the number of inclusions that are concentrators of elastic stresses at grain bounda-

\footnotetext{
*bvv260170@ukr.net
} 
ries as a result of dissolution. The authors of [5] also believe that homogenization annealing suppresses or, at least, reduces the probability of the partial melting at grain boundaries as a result of burning during superplastic deformation of the samples at high homological temperatures close to the melting temperature of the alloy. The main conclusion of this work can be considered the assertion that the thermally treated samples of alloy AA7475 are not observed after preliminary annealing for $2 \mathrm{~h}$, the formation and development of fibrous structures. According to the authors of [5], preliminary homogenization annealing of alloy AA7475 samples for $2 \mathrm{~h}$, carried out immediately before the mechanical tests, effectively suppresses fiber formation. In [8], samples of alloy AA7475 were also studied, whose homogenization annealing for $2 \mathrm{~h}$ was also carried out at $516{ }^{\circ} \mathrm{C}$. The study found that annealing does not have a real impact on the formation and development of fibrous structures. Fibers longer than $100 \mu \mathrm{m}$ were observed both in the samples that did not undergo preliminary annealing and in annealed samples of this alloy. The authors of [8] concluded that the presence of preliminary homogenization annealing does not significantly affect the formation and development of fibrous structures.

Thus, the issue of the effect of homogenizing annealing on the formation and development of fibrous structures is still not fully clarified. Similarly, the mechanism of the formation and growth of fibrous structures, that is, the mechanism of microsuperplasticity, has not been finally established. This article discusses the effect of preliminary high-temperature homogenization annealing on microstructural changes in the samples of alloy 1933 of the $\mathrm{Al}-\mathrm{Zn}-\mathrm{Mg}-\mathrm{Cu}$ system and their correlation with the superplasticity and microsuperplasticity of the alloy.

\section{MATERIALS AND METHODS}

The studied alloy 1933 has the following chemical composition: $\mathrm{Zn}$ (6.2-7.0 \%), $\mathrm{Mg}$ (1.6-2.2\%), $\mathrm{Cu}$ (0.8$1.2 \%), \mathrm{Zr}(0.10-0.18 \%), \mathrm{Fe}(0.15 \%), \mathrm{Mn}(0.1 \%), \mathrm{Si}$ $(0.1 \%)$, Ti (0.05\%), Cr (0.05\%), base Al, wt. \% [9, 10]. The initial ingot underwent typical heat treatment: quenching at $465-475{ }^{\circ} \mathrm{C}$ during $20 \mathrm{~min}$ and aging according to the T2 mode (the first stage $-120^{\circ} \mathrm{C}, 3 \mathrm{~h}$; the second stage $-170^{\circ} \mathrm{C}, 12 \mathrm{~h}$ ).

Alloy 1933 is widely used in the aircraft industry. In particular, it was used for the manufacture of largesize forgings and stampings of An-225 Mriya aircraft [10]. This alloy has a high fracture toughness and surpasses in this respect alloys of a similar purpose 7050 , 7175 , and $7040[9,10]$.

Experimental samples with the dimensions of the working part of $2.0 \times 4.5 \times 10 \mathrm{~mm}^{3}$ were subjected to homogenizing annealing in a SUOL-0,4.4/12-M2-U4.2 tubular muffle furnace at $520^{\circ} \mathrm{C}$ for $2 \mathrm{~h}$ followed by cooling in the air at room temperature.

Mechanical tests of the samples were carried out in the air. The samples were deformed by tension in the creep mode at a constant flow stress by the technique that was repeatedly used earlier and described in [6, 11].

The microstructure was studied using a MIM-6 optical microscope and a Tescan VEGA 3 LMH scanning electron microscope. To identify grain boundaries, a universal etchant of the following composition was used: $17 \mathrm{ml}$ of $\mathrm{HNO}_{3}, 5 \mathrm{ml}$ of $\mathrm{HF}, 78 \mathrm{ml}$ of $\mathrm{H}_{2} \mathrm{O}$. The average grain size was determined by the random secant method.

The phase composition was studied by diffractometric analysis using a DRON-4 X-ray diffractometer. Vickers microhardness was measured at room temperature in the air using a PMT-3 microhardness tester.

Local chemical analysis was performed using a Tescan VEGA 3 LMH scanning electron microscope equipped with a Bruker XFlash 5010 energy dispersive $\mathrm{X}$-ray microanalysis attachment.

\section{RESULTS AND DISCUSSION}

\subsection{Effect of Annealing on the Microstructure}

It is known [9] that the main tasks of homogenization annealing are the dissolution of nonequilibrium phases, the equalization of the chemical composition along the sample cross-section, and the reduction of internal stresses. The acceleration of diffusion processes is achieved by increasing the homogenization temperature. During the homogenization of multicomponent aluminum alloys, along with the dissolution of the main alloying elements of the alloy, the process of decomposition of an $\alpha$-solid solution based on aluminumcontaining atoms of manganese, chromium, titanium, and zirconium occurs. The intensity of this process also increases with the increase in temperature. In this regard, the homogenization temperature should be as high as possible, taking into account the melting points of nonequilibrium eutectics, which may be present in the microstructure of multicomponent aluminum alloys. Many researchers attribute the manifestation of microsuperplasticity to the presence of inhomogeneities in the chemical composition and inclusions of secondary phases in deformed samples. High-temperature annealing effectively affects the dissolution of secondary phases and equalizes the concentration inhomogeneity of the alloying elements in an $\alpha$-solid solution based on aluminum. In this work, similarly to $[5,8]$, the annealing temperature corresponded to the optimum temperature of manifestation of the superplasticity of the studied alloy $\left(520^{\circ} \mathrm{C}\right)[11]$. Heating of the samples of alloy 1933 to this temperature and maintaining it may lead to the melting of quasibinary eutectics $\alpha_{\mathrm{Al}}+\mathrm{AlZn}_{2}$ at $475{ }^{\circ} \mathrm{C}$ and $\alpha_{\mathrm{Al}}+\mathrm{Mg}_{3} \mathrm{Zn}_{3} \mathrm{Al}_{2}$ at $489^{\circ} \mathrm{C}$. Ternary eutectic $\alpha \mathrm{Al}+\mathrm{AlZn}_{2}+\mathrm{Mg}_{3} \mathrm{Zn}_{3} \mathrm{Al}_{2}$ and quaternary eutectic $\alpha_{\mathrm{Al}}+\mathrm{AlZn}_{2}+\mathrm{Mg}_{3} \mathrm{Zn}_{3} \mathrm{Al}_{2}+\mathrm{Al}_{2} \mathrm{CuMg}$ melt at $475{ }^{\circ} \mathrm{C}$ [12] However, the annealing time $(2 \mathrm{~h})$ was still not sufficient for the $\alpha$-solid solution based on aluminum to decay and new intermetallic phases to form.

Fig. 1a shows a typical form of the initial microstructure of alloy 1933. It is clear that the initial grain structure is heterogeneous. It was found that the average grain size in the source samples of alloy 1933 is $15 \mu \mathrm{m}$. Metallographic studies of the source ingot showed that the microstructure contains the secondary phase particles, which are located in the body of grains as well as on their boundaries (Fig. 1a). Fig. 1b shows a typical microstructure of alloy 1933 after homogenization annealing. The differences in the structural phase state before and after annealing are significant. The 
grain structure of the alloy became more equiaxial, although the graininess remained. The average grain size increased slightly compared with the initial state and was approximately $23 \mu \mathrm{m}$. It should be noted that grain growth during heat treatment is very limited. Perhaps this is caused by the presence of dispersed inclusions of $\mathrm{Al}_{3} \mathrm{Zr}$ phase at the grain boundaries, as well as small dispersoids of phases which include Ti and Cr. Fig. 1 also shows signs of fusion of particles of secondary phases in the body of grains and along their boundaries, which may occur during annealing of the alloy.

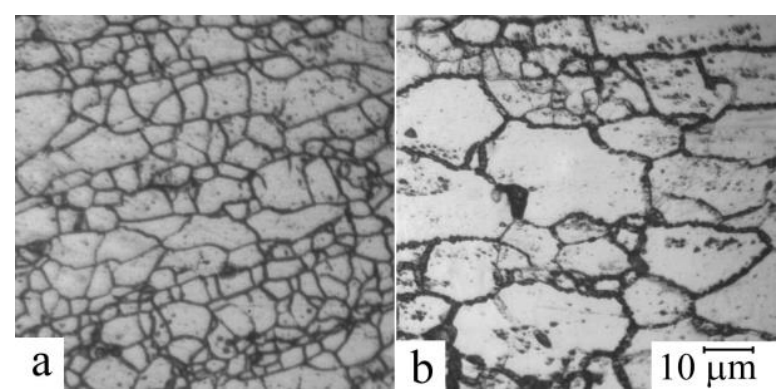

Fig. 1 - A typical form of a section of the initial microstructure of alloy 1933 (a) and the microstructure of the sample after homogenization of the alloy for $2 \mathrm{~h}$ at $520^{\circ} \mathrm{C}$ (b) (optical microscopy)

Diffractometric studies were conducted to study the phase composition of alloy 1933. Fig. 2a shows the radiograph of the source sample of alloy 1933. The intensity of X-ray diffraction peaks corresponds to an $\alpha$-solid solution based on aluminum ( $\alpha_{\mathrm{Al}}$-phase). The presence of diffraction peaks of the $\eta$-phase $\left(\mathrm{MgZn}_{2}\right)$, the T-phase $\left(\mathrm{Mg}_{3} \mathrm{Zn}_{3} \mathrm{Al}_{2}\right)$ and the S-phase $\left(\mathrm{Al}_{2} \mathrm{CuMg}\right)$ is also typical for the initial microstructure. Several peaks in the Xray diffraction pattern were not possible to identify; however, the peaks at $51.5^{\circ}$ and $53.4^{\circ}$ may correspond to $\mathrm{Al}_{3} \mathrm{Zr}$ phase [13]. Particles of this phase can also be present in alloy $1933[9,10]$. Fig. $2 b$ shows the radiograph of the sample of alloy 1933 subjected to homogenization annealing. It is found that the X-ray diffraction peaks correspond to an $\alpha$-solid solution based on aluminum ( $\alpha_{\mathrm{Al}}$-phase). The sample subjected to homogenization annealing contains no diffraction peaks of the $\eta$-phase, T-phase, and S-phase. This fact suggests that either these phases are completely dissolved in the aluminum matrix or they are present in an insignificant amount. Also, a comparison of the diffraction patterns in Fig. 2a and Fig. 2b shows that homogenization annealing leads to a redistribution of crystallite orientations of an $\alpha$-solid solution based on alumina. This is reflected in a change in the diffraction intensity ratio of the peaks of the $\alpha_{\mathrm{Al}}$-phase. In the annealed samples, a slight narrowing of the peaks of the $\alpha_{\mathrm{Al}}$-phase is observed, which may be associated with the removal of secondary microstresses in the alloy microstructure.

Initially, the alloy 1933 microhardness was HV-105. After annealing of the source sample at $520{ }^{\circ} \mathrm{C}$ for $2 \mathrm{~h}$ the $\mathrm{HV}$ value is 56 . That is, the thermal treatment causes the softening of the studied alloy. The observed decrease in microhardness is apparently caused by the following two main factors: the dissolution of particles of secondary phases and the phenomenon of burnout of the structure - the fusion of nonequilibrium eutectics.
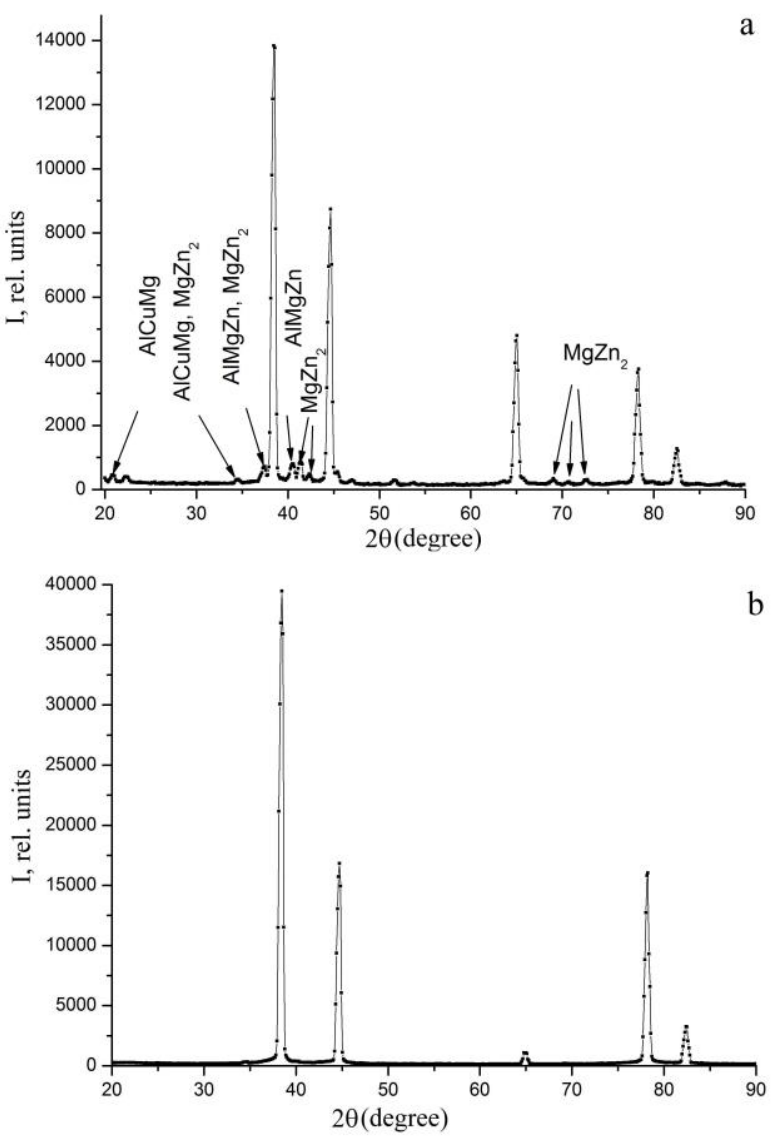

Fig. 2 - X-ray diffraction pattern of the source sample of alloy 1933 (a) and the sample subjected to homogenization for $2 \mathrm{~h}$ at $520^{\circ} \mathrm{C}(\mathrm{b})$

\subsection{Effect of Annealing on the Superplasticity}

Mechanical tests carried out in the creep mode at a constant flow stress in the study [11] showed that the samples of alloy 1933 exhibited superplasticity. The optimal conditions for the manifestation of the superplasticity effect by the samples of the studied alloy 1933 are the following: temperature $T=520{ }^{\circ} \mathrm{C}$, flow stress $\sigma=5.5 \mathrm{MPa}$. The maximum relative elongation of the samples to failure $\delta$, superplastically deformed at $T=520^{\circ} \mathrm{C}$ and $\sigma=5.5 \mathrm{MPa}$ with a true strain rate of $1.2 \cdot 10^{-4} \mathrm{~s}^{-1}$, was $260 \%$.

The research showed that the effect of preliminary heat treatment on the mechanical behavior of alloy 1933 under conditions of superplastic deformation is insignificant. Mechanical tests demonstrated that the flow stress value at which the annealed samples of alloy 1933 show the effect of superplasticity, as well as the rate sensitivity of the flow stress $m$, were practically independent of subjecting the alloy to a homogenization temperature of $520^{\circ} \mathrm{C}$ for $2 \mathrm{~h}$. Nevertheless, the tensile tests at constant applied stress showed that the maximum elongation to fracture of the samples subjected to homogenization is reduced to $220 \%$. This reduction is probably because the initial grain size of the annealed samples of alloy 1933 is somewhat increased compared to the samples without homogenization.

To better understand the physical essence of the deformation processes occurring during the superplastic 
deformation of alloy 1933, the study of the deformation relief of the working part of the samples was conducted. It is formed on the surface of deformed crystallites during deformation and does not disappear after the termination of the load. Fig. 3 shows the characteristic types of the deformation relief formed on the surface of the working part of the alloy 1933 samples deformed to failure under optimal conditions of superplasticity. The types of the deformation relief of the source samples without homogenization (Fig. 3a) and annealed samples (Fig. 3b) have some differences.
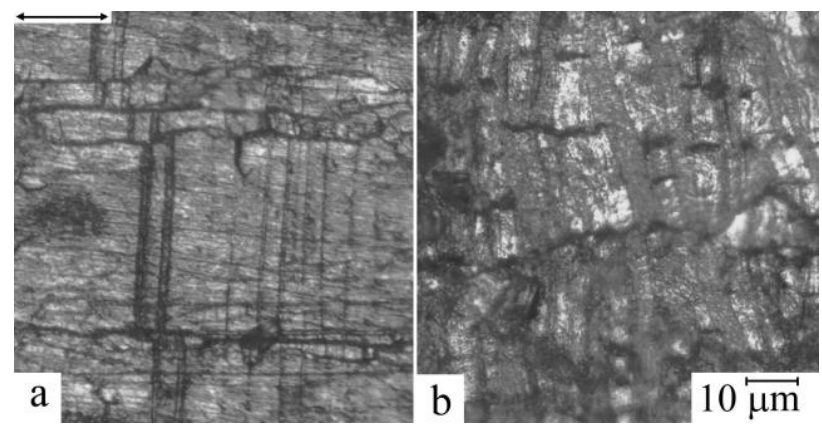

Fig. 3 - Typical types of the deformation relief of the surface of the working part of the samples of alloy 1933 deformed to failure at $T=520^{\circ} \mathrm{C}$ and $\sigma=5.5 \mathrm{MPa}$ : the source sample (a), the annealed sample (b). The direction of extension is indicated by the arrow

The research shows that during superplastic deformation, grain boundary sliding occurs in the samples of alloy 1933. The development of grain boundary sliding in the samples of alloy 1933, that have not undergone homogenization, is evidenced by the formation of the developed deformation relief on the previously polished surface of the working part of the samples, as well as the presence of characteristic displacements and breaks of marker scratches at the boundaries of the grains that slipped relative to each other (Fig. 3a). The study [11] found that the contribution of grain boundary sliding to the local deformation of the samples of alloy 1933 in different areas of their working parts is significantly different. Evaluation calculations showed that its values are quite large and in the range from $50 \%$ to $80 \%$.

The samples subjected to homogenization annealing did not show any distinct displacement and discontinuity of marker scratches at the grain boundaries (Fig. $3 \mathrm{~b}$ ). However, one can say that neighboring grains are rotated without noticeable sliding along the grain boundaries. This is evidenced by the fact that the marker scratches applied to the pre-polished surface of the working part of the sample before its deformation, after superplastic deformation, are misoriented relative to each other. The absence of clear displacements along the grain boundaries of marker patterns is apparently caused by the localization of deformation along the grain boundaries in their "mantles", i.e. in the area of grains close to their boundaries [14]. In this case, it is assumed that there are no reasons preventing the movement of dislocations in the boundary region. It is homogenization that apparently allows this process to be realized, and the dissolution of grain boundary segregations and secondary phases near grain boundaries occurs because of the homogenization. It is also possible that an increase in the contribution of intragranular dislocation slip to the total deformation in the homogenized samples causes the difference in the nature of the deformation relief. Redistribution of the contributions to the total deformation from the grain boundary sliding to intragranular dislocation slip may also be the cause of the decrease in elongation to the failure of the annealed samples.

Porosity is present in the samples of alloy 1933 deformed to failure under conditions of superplasticity. The morphological features and mechanisms of the formation and development of deformation porosity were not specifically studied in this work. However, analysis of the available experimental data suggests that preliminary homogenization annealing does not significantly affect the formation and development of porosity in the samples of the studied alloy deformed to fracture under conditions of superplasticity.

\subsection{Effect of Annealing on the Microsuper- plasticity}

\subsubsection{Fibers in the Deformed Samples}

Earlier studies $[11,15]$ reported that during superplastic deformation, fibrous structures localized in surface pores and microcracks were detected in the samples of alloy 1933. Fig. 4 shows typical types of the deformation relief of a non-homogenized sample of alloy 1933. The sample was deformed to failure at $T=520^{\circ} \mathrm{C}$ and $\sigma=5.5 \mathrm{MPa}$. In surface pores and cracks, fibers with a length of about $5 \mu \mathrm{m}$ and up to $50 \mu \mathrm{m}$ are observed. The fibrous structures are parallel to the direction of the axis of extension of the sample. To determine the differences in the chemical composition of the fiber section and the surface area of the superplastically deformed non-homogenized sample of alloy 1933, they were subjected to energy-dispersive X-ray microanalysis. The areas in which the chemical composition was determined are marked with numbers 1 and 2 in Fig. 4. Fig. 5 shows the energy spectra of $\mathrm{Al}, \mathrm{Zn}, \mathrm{Mg}$, $\mathrm{Cu}$, and $\mathrm{O}$ obtained by studying these areas. Fig. 5 also shows the chemical composition of a studied area near each energy spectrum. It was found that the concentration of $\mathrm{Mg}$ atoms in both areas is increased in comparison with the average concentration of magnesium in the alloy. At the same time, the concentration of $\mathrm{Zn}$ and $\mathrm{Cu}$ atoms for both the fiber and the sample surface is almost two times lower than their average content in the alloy. In the studies $[11,15]$, it was assumed that the formation and development of fibrous structures in alloy 1933 during superplastic deformation occurs by the mechanism of a viscous flow of material formed as a result of the partial melting of alloy sections containing an increased concentration of alloying elements. One of the most probable reasons for the formation of the liquid phase, in this case, was assumed to be the local melting of sections that contain an increased concentration of magnesium, zinc, and copper, which lower the melting point of the alloy, as well as the melting of eutectics, which include $\mathrm{AlZn}_{2}, \mathrm{Mg}_{3} \mathrm{Zn}_{3} \mathrm{Al}_{2}$, and $\mathrm{Al}_{2} \mathrm{CuMg}$ phases. However, the results of energy dispersive X-ray microanalysis show that only the concen- 
tration of magnesium atoms is increased in the fibers and the surface layer of the samples, and oxygen is also present there.

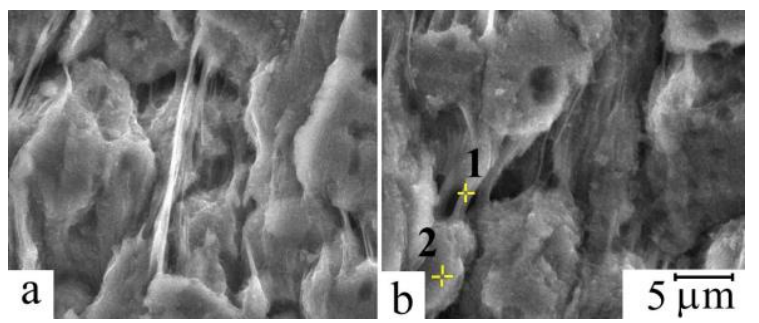

Fig. 4 - SEM micrograph of fibrous structures in the sample of alloy 1933 deformed to fracture at $T=520^{\circ} \mathrm{C}, \sigma=5.5 \mathrm{MPa}$ : (a), (b) are different sections of the sample
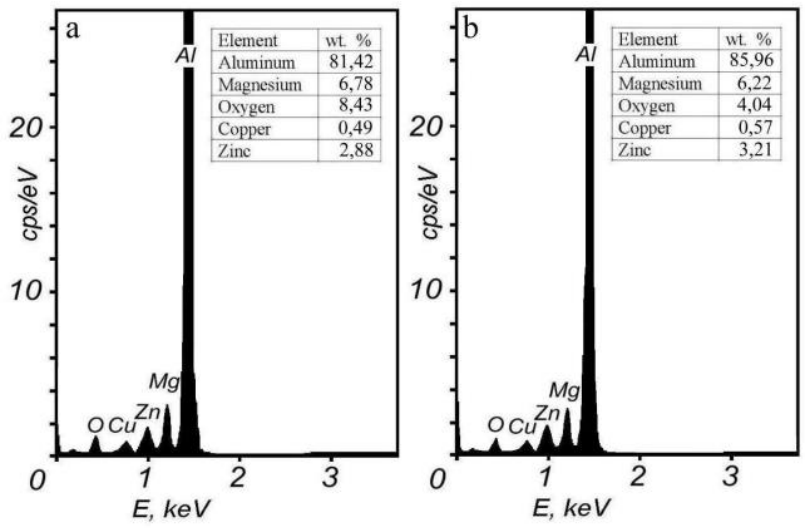

Fig. 5 - The energy spectra of $\mathrm{Al}, \mathrm{Zn}, \mathrm{Mg}, \mathrm{Cu}$, and $\mathrm{O}$ obtained in the study of the microstructure of alloy 1933: (a) the spectrum obtained from point 1 in Fig. 4; (b) the spectrum obtained from point 2 in Fig. 4

Fig. 6 shows typical types of the deformation relief formed on the surface of the working part of the superplastically deformed samples of alloy 1933, which were subjected to homogenization annealing. In surface pores (Fig. 6), fibrous structures are also present. The length and diameter (thickness) of fibrous structures in the pre-annealed samples are approximately the same as in the samples that have not undergone homogenization annealing. Energy dispersive X-ray microanalysis showed that aluminum, magnesium, zinc, copper, and oxygen are present in the composition of the fibers (Fig. 7). The concentration of magnesium atoms in the composition of the fibers is increased compared to the average concentration in the alloy. Increased magnesium content was also found in surface areas near the location of the fibers (Fig. 6). The concentration of $\mathrm{Zn}$ and $\mathrm{Cu}$ both in the fiber and on the surface of the sample is almost two times lower than their average content in the alloy. Oxygen is present in the fibers and the surface layer of the samples.

\subsubsection{Discussion of the Mechanism of Micro- superplasticity}

To date, several mechanisms of the formation and development of fibrous structures have been considered and discussed [2-8]. For one reason or another, all the proposed mechanisms of microsuperplasticity are associated with the presence of inclusions of secondary phases

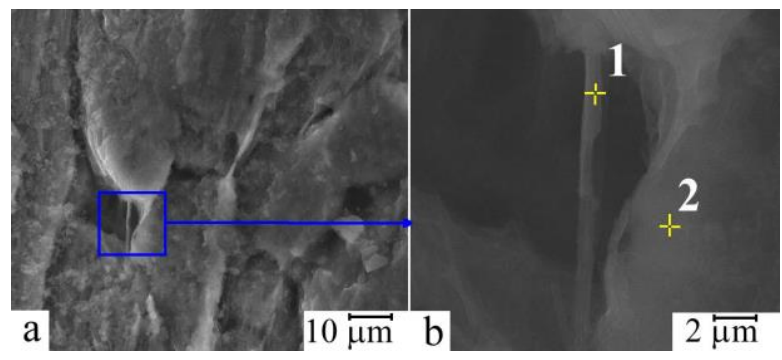

Fig. 6 - SEM micrograph of fibrous structures in the preliminarily annealed sample of alloy 1933 deformed to failure at $T=520^{\circ} \mathrm{C}$ and $\sigma=5.5 \mathrm{MPa}$ : (a) section of the sample; (b) enlarged fragment of the highlighted section in Fig. 6a
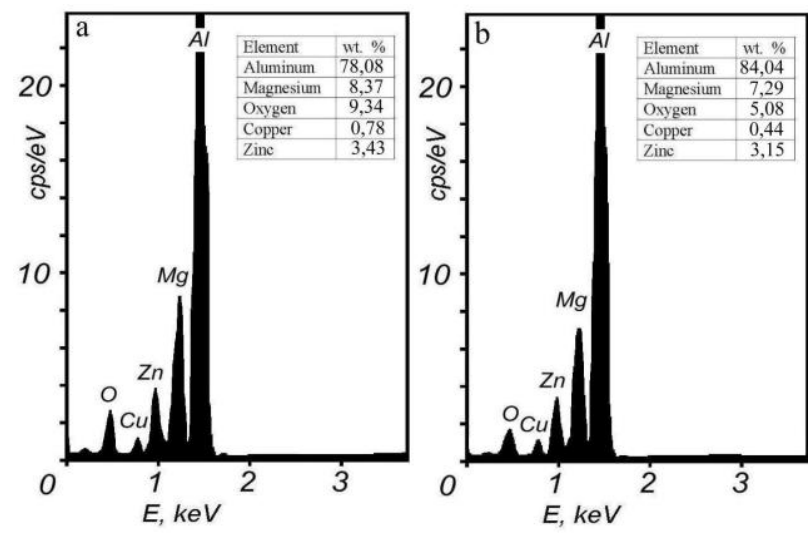

Fig. 7 - The energy spectra of $\mathrm{Al}, \mathrm{Zn}, \mathrm{Mg}, \mathrm{Cu}$, and $\mathrm{O}$ obtained in the study of the microstructure of alloy 1933: (a) the spectrum obtained from point 1 in Fig. 6; (b) the spectrum obtained from point 2 in Fig. 6

or segregation of alloying elements in the alloy. However, the supposed role of these structural components in the implementation of the microsuperplasticity mechanism is contradictory. Thus, an extensive series of works is devoted to the formation of fibers by the mechanism of viscous flow of material resulting from the partial melting of alloys [5-7, 15, 16]. It is assumed that the appearance of local inclusions of the liquid phase is caused by the melting of eutectic components, intermetallic phases with a low melting point or an aluminum-based solid solution containing an increased concentration of alloying elements. One of the reasons for the appearance of the liquid phase during superplastic deformation may be contact melting [17]. In [18], it was pointed out that in the Mg- $15 \% \mathrm{Al}-1 \% \mathrm{Zn}$ alloy, fibers are formed by the single-crystal plasticity mechanism from the $\beta$-phase $\left(\mathrm{Mg}_{17} \mathrm{Al}_{12}\right)$ present in the alloy. And the more this phase is present in the alloy, the more intensively the formation and development of fibrous structures occur during superplastic deformation. According to the authors of [18], the important fact is that this phase is characterized by higher mobility of dislocations during plastic deformation than the magnesium matrix of the alloy. According to the authors of [19], the formation of fibrous structures in the Al-Mg$\mathrm{Cu}$-Si alloy during superplastic deformation occurred as a result of the growth of oxides, which were formed during grain boundary sliding from the $\mathrm{Mg}_{5} \mathrm{Si}_{6}$ phase located at the grain boundaries. The diffusion mechanisms of fiber formation were repeatedly discussed [20,21], where the phase composition of the alloys also plays an 
important role. For the above-mentioned mechanisms of formation of fibrous structures, homogenization would play a negative role and would probably lead to the impossibility of fiber formation. However, in the studied alloy 1933 after homogenization annealing, fibers are observed. Moreover, in their morphological characteristics, they are the same as in the alloy without homogenization. In [22], a superplastic flow of the material in local microvolumes free of precipitation of secondary phase dispersoids was assumed as a mechanism of fiber formation in the $\mathrm{Al}-8 \% \mathrm{Fe}-2 \% \mathrm{Mo}$ alloy. However, to implement this mechanism, it is necessary to have a very fine nanocrystalline structure, for example, as in [23]. While the investigated alloy 1933 has a rather large grain size.

Thus, the mechanisms of fiber formation discussed in the literature cannot fully explain their origin in the studied alloy 1933. In general, the problem of the relationship between structure formation and properties of solids under nonequilibrium conditions, namely, the conditions for the realization of the superplasticity effect, is still not completely clear. Therefore, the search for new alternative mechanisms for the formation of fibrous structures is highly relevant.

The morphology of the fibers suggests that their formation and development involves the implementation of high local deformations and stable plastic flow in small microvolumes. The fact that fibers were observed only in the deformed samples indicates their deformation nature.

An analysis of the results of energy dispersive X-ray microanalysis suggests that the concentration of magnesium atoms in local areas is increased by about 3 times compared with the average concentration. At the same time, the concentration of zinc and copper atoms is approximately 2 times lower than the average concentration in the alloy. Since the deformation of the samples is carried out in the air, the surface of the samples is oxidized in the process of deformation. $\mathrm{MgO}$ is the initial oxidation product of aluminum alloys containing more than $1 \%$ magnesium [24]. In the process of further oxidation, the oxide $\mathrm{Al}_{2} \mathrm{MgO}_{4}$ and then $\mathrm{Al}_{2} \mathrm{O}_{3}$ is formed, whereupon the oxidation process stops. The characteristic ratio of oxygen and magnesium concentrations indicates that mainly magnesium is concentrated in the composition of $\mathrm{MgO}$ and $\mathrm{Al}_{2} \mathrm{MgO}_{4}$ oxides, which apparently cover the external surface of the fiber and the surface of the deformed samples [25].

During intensive oxidation of the alloy in the process of superplastic deformation, magnesium atoms from the surface layers also pass from the bulk of the alloy into the oxide film. Therefore, the actual equilibrium magnesium content in the alloy after the formation of an oxide layer will be slightly lower than the magnesium content before oxidation. However, the upper oxide layers make an overestimated specific contribution to the formation of the energy spectrum during energy dispersive X-ray microanalysis. Apparently, this is why the results of energy dispersive X-ray microanalysis show an increased concentration of magnesium compared with that on average for the alloy composition. Since the concentration of $\mathrm{Zn}$ and $\mathrm{Cu}$ atoms both for the fiber and for the sample surface is almost two times lower than their average content in the alloy, it can conditionally be accepted that the concentration of $\mathrm{Mg}$ atoms is approximately 2 times higher. However, the research results show a 3 times higher concentration of magnesium. Moreover, the higher oxygen concentration in the studied sections also indicates the presence of a local burn in the alloy. Thus, the melting of local sections of the sample of alloy 1933 upon heating it to the test temperature and during superplastic deformation is likely caused by local inhomogeneity in the distribution of magnesium in the aluminum-based $\alpha$-solid solution. Homogenization conducted for $2 \mathrm{~h}$ apparently also does not completely eliminate this heterogeneity.

If we accept the point that the fibers are formed from a viscous melt, the question arises of the amount of such a melt required for the formation of fibers. Let us analyze what the volume of the liquid phase in alloy 1933 should be so that the fibers observed in the alloy are formed from it. For this, we compare the volume of the substance of which one filament fiber consists of with the volume of the substance in one grain of the same alloy. An average fiber can conditionally be considered as a cylindrical thread with a diameter of $1 \mu \mathrm{m}$ and a length of $50 \mu \mathrm{m}$. The average grain size in alloy 1933 in the initial state is $15 \mu \mathrm{m}$. One can conditionally consider the grain as a ball. Thus, having calculated the volume of the cylinder and the ball, we get that the volume of the substance of one filamentary fiber will be comparable to about half the volume of the substance in one grain. However, accumulations of fibers are observed, the distance between which is several micrometers (Fig. 8a). Since several fibers can be attached to one grain, building material is needed for their formation and development, which is several times larger than the volume of the substance in one grain. Therefore, for the formation of fiber in alloy 1933 by the mechanism of the viscous flow of matter, a lot of building material was needed. The presence of such significant inclusions of the liquid phase in local places would inevitably lead to liquid crystal embrittlement.

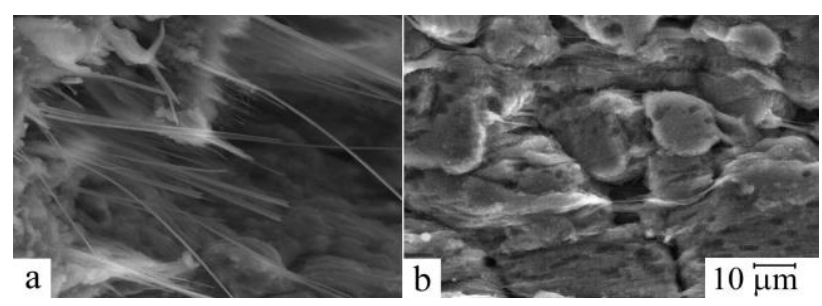

Fig. 8 - Types of fibrous structures in different sections of the sample of alloy 1933 deformed to failure at $T=520^{\circ} \mathrm{C}$ and $\sigma=5.5 \mathrm{MPa}$ (scanning electron microscopy)

Based on the type of fibrous structures, the type of the deformation relief, and taking into account the above estimates, the complex mechanism of the development of fibrous structures seems more probable. It should be noted that the possibility of the simultaneous action of several mechanisms during the formation of fibrous structures was reported in [26]. It is noteworthy that the diameter of short fibers with a length of several micrometers (Fig. 8b) is the same as for long fibers (Fig. 8a). One can say that the diameter of the fibers does not depend on their length. Therefore, apparently, embryos of future fibers are formed by the mechanism described in [6], from the local inclusions of the viscous 
phase at the initial stage of opening of surface pores. In this case, oxidation processes are important. It is a layer of $\mathrm{MgO}, \mathrm{Al}_{2} \mathrm{MgO}_{4}$, and $\mathrm{Al}_{2} \mathrm{O}_{3}$ oxides that creates a fairly strong fiber frame during its nucleation, the shape of which determines the thickness of the fiber and is preserved during its further growth. The further development of the fibers occurs probably due to the simultaneous implementation of a complex of various deformation mechanisms that develop during the superplastic flow of alloy 1933 at a high homological temperature. Apparently, along with the viscous flow of the liquid-solid phase, the diffusion and dislocation strain mechanisms can also contribute to the fiber growth.

The mechanism proposed above for the formation and development of fibers during superplastic deformation of the samples of alloy 1933 may be also characteristic of other multicomponent aluminum alloys. For example, the concentration of alloying elements along the fiber length in several aluminum alloys was studied in detail in $[5,6]$. It was found that the concentration of alloying elements along the fibers is heterogeneous. There are sections of fibers, usually close to their center, where the concentration of magnesium is the highest. In places of maximum magnesium concentration, the concentration of other alloying elements is reduced [5]. Places with an increased concentration of magnesium are probably formed at the moment of fiber nucleation. Their further growth was carried out by a complex of other mechanisms of development of fibrous structures. Nevertheless, further studies are required to better understand the formation mechanism of fibrous structures.

\section{CONCLUSIONS}

1) Annealing of the samples of alloy 1933 at $520^{\circ} \mathrm{C}$ for $2 \mathrm{~h}$ leads to the dissolution and melting of particles of the $\eta$-phase $\left(\mathrm{MgZn}_{2}\right)$, T-phase $\left(\mathrm{Mg}_{3} \mathrm{Zn}_{3} \mathrm{Al}_{2}\right)$, and Sphase $\left(\mathrm{Al}_{2} \mathrm{CuMg}\right)$. During annealing, the orientation of the crystallites of the $\alpha$-solid solution based on aluminum is redistributed and internal microstresses are

\section{REFERENCES}

1. O.A. Kaibyshev, Superplasticity of Alloys Intermetallides and Ceramics (New York: Springer-Verlag: 1992).

2. W.J.D. Shaw, Mater. Lett. 4, 1 (1985).

3. W.J.D. Shaw, J. Mater. Sci. Lett. 24, 4114 (1989).

4. M.G. Zelin, Acta Mater. 45, 3533 (1997)

5. J.J. Blandin, B. Hong, A. Barloteaux, M. Suery, G. Lesperance, Acta Mater. 44, 2317 (1996).

6. V.P. Poida, V.V. Bryukhovetskii, A.V. Poida, R.I. Kuznetsova, V.F. Klepikov, D.L. Voronov, Phys. Met. Metallogr. 103 No 4, 414 (2007).

7. C.L. Chen, M.G. Tan, Mater. Sci. Eng. A 298, 235 (2001).

8. J.H. Robinson, M.A. Rust, R.I. Todd, Mater. Sci. Forum 551552, 135 (2007).

9. I.N. Fridlyander, Wrought aluminium alloys for structural applications, (Moscow: Metallurgiya: 1979).

10. I.N. Fridlyander, Metallovedenie $i$ Termicheskaya Obrabotka Metallov. 7, 24 (2002).

11. V.P. Poida, D.E. Pedun, V.V. Bryukhovetskii, A.V. Poida, R.V. Sukhov, A.L. Samsonik, V.V. Litvinenko, Phys. Met. Metallogr. 114 No 9, 779 (2013).

12. V.I. Elagin, V.V. Zakharov, M.M. Drits, Structure and Properties of Alloys of Al-Zn-Mg System (Moscow: Metallurgiya: 1982).

13. K.E. Knipling, D.C. Dunand, D.N. Seidman, Zeitschrift für removed in the body of the material. In the annealed samples, the grain size increases slightly, the grains become more equiaxed, but the graininess remains.

2) The effect of preliminary homogenization annealing on the mechanical behavior of alloy 1933 under conditions of superplastic deformation is insignificant. The values of the optimum flow stress and the velocity sensitivity index of the flow stress $m$ are practically independent of the annealing of the alloy samples for $2 \mathrm{~h}$ at $520^{\circ} \mathrm{C}$. However, the maximum elongation before failure of the samples that were subjected to homogenization decreases to $220 \%$. This is caused by the redistribution of contributions to the total deformation from grain boundary sliding to intragranular dislocation slip.

3) Fibrous structures were found in the surface pores and cracks formed in the working part of the samples of alloy 1933 during superplastic deformation. The presence of fibrous structures is characteristic of both non-homogenized samples and samples that underwent preliminary homogenization. It was found that the concentration of $\mathrm{Mg}$ atoms in the fibers is increased in comparison with the average concentration of magnesium in the alloy. At the same time, the concentration of $\mathrm{Zn}$ and $\mathrm{Cu}$ atoms is almost two times lower than their average content in the alloy.

4) A mechanism for the formation and development of fibers is proposed. According to this mechanism, the nucleation of fibers occurs during the opening of surface grain-boundary pores from a viscous material formed as a result of the local melting of the alloy. Their further development can occur due to the simultaneous implementation of a complex of various deformation mechanisms leading to an increase in fiber length during the further opening of surface pores. Along with the viscous flow of the liquid-solid phase, the diffusion and dislocation deformation mechanisms that develop during the superplastic flow of alloy 1933 at high homological temperatures also contribute to fiber growth. In this case, important are the oxidation processes responsible for the formation of a fiber frame.

Metallkunde 97, 246 (2006)

14. R.C. Gifkins, Metallurgical Transactions A 7, 1225 (1976).

15. V.V. Bryukhovetsky, A.V. Poyda, V.P. Poyda, D.E. Milaya, Probl. At. Sci. Technol. 114, 94 (2018).

16. A.V. Pojda, V.V. Bryukhovets'ky, D.L. Voronov, R.I. Kuznetsova, V.F. Klepikov, Metallofiz. Nov. Tekhnol. 27 No 3, 317 (2005).

17. V.V. Bryukhovetsky, R.I. Kuznetsova, N.N. Zhukov, V.P. Poida, V.F. Klepikov, phys. status solidi a 202 No 9, 1740 (2005).

18. S.W. Lee, Y.L. Chen, H.Y. Wang, Mater. Sci. Eng. A 464, 76 (2007)

19. S. Li, Z. Huang, S. Jin, Metals 9, 1 (2019).

20. T.R. Chen, J.C. Huang, Metall. Mater. Trans. A 30, 53 (1999).

21. F. Cao, Z. Li, N. Zhang, H. Ding, F. Yu, L. Zuo, Mater. Sci. Eng. A 571, 167 (2013).

22. S.F. Clays, J.W. Jones, J.E. Allison, Dispersion Strengthened Aluminum Alloys (TMS: Ed. by Y.W. Kim and W.M. Griffith: 1988).

23. G. Dirras, Mater. Lett. 64, 1163 (2010).

24. K. Kim, Surf. Interface Analys. 47, 429 (2015).

25. S. Das, A.R. Riahi, X. Meng-Burany, A.T. Morales, A.T. Alpas, Mater. Sci. Eng. A 531, 76 (2012).

26. B. Zhang, Z. Wei, Y. Wang, Q. Jin, D.J. Mynors, Mater. Sci. Forum 447-448, 253 (2004). 


\title{
Вплив гомогенізації на проявлення надпластичності і мікронадпластичності алюмініевого сплаву системи $\mathrm{Al}-\mathrm{Zn}-\mathrm{Mg}-\mathrm{Cu}$
}

\author{
В.В. Брюховецький ${ }^{1}$, Д.Є. Мила ${ }^{1,2}$, В.П. Пойда ${ }^{2}$, А.В. Пойда ${ }^{1}$ \\ ${ }^{1}$ Інститут електрофбізики і радіаційних технологій НАН України, вул. Чернишевська, 28, \\ a/c 8812, 61002 Харків, Україна \\ ${ }^{2}$ Харківський національний університет ілені В.Н. Каразіна, майдан Свободи, 4, 6100о Харків, Украйна \\ В статті вивчено вплив високотемпературного гомогенізаційного відпалу на мікроструктурні змі- \\ ни в алюмінієвому сплаві 1933 та їх взаємозв’язок з проявленням надпластичності і мікронадпласти- \\ чності. Встановлено, що відпал сплаву 1933 при температурі $520^{\circ} \mathrm{C}$ протягом 2 годин призводить до \\ розчинення та оплавлення частинок $\eta$-фази $\left(\mathrm{MgZn}_{2}\right)$, T-фрази $\left(\mathrm{Mg}_{3} \mathrm{Zn}_{3} \mathrm{Al}_{2}\right)$ і $\mathrm{S}$-фази $\left(\mathrm{Al}_{2} \mathrm{CuMg}\right)$, наяв- \\ ність яких є характерною для вихідної мікроструктури сплаву. Наслідком відпалу е перерозподіл кри- \\ сталографічної орієнтації кристалітів $\alpha$-твердого розчину на основі алюмінію та зменшення внутріш- \\ ніх мікронапружень в об’емі сплаву. Установлено, що попередня термообробка незначно впливае на \\ механічну поведінку сплаву 1933 в умовах надпластичної деформації. Волокнисті структури, процес \\ утворення і розвитку яких називають мікронадпластичністю, спостерігаються як в зразках, що не \\ пройшли попередній гомогенізаційний відпал, так і в відпалених зразках. Концентрація атомів $\mathrm{Mg}$ у \\ волокнах є підвищеною у порівнянні з середньою концентрацією в сплаві. Однак концентрація атомів \\ $\mathrm{Zn} \mathrm{i} \mathrm{Cu}$ у волокнах майже вдвічі менша, ніж в сплаві загалом. Запропоновано механізм утворення і \\ розвитку волокон, згідно якому зародження волокон зумовлене в'язким плином матеріалу, що утво- \\ рився через плавлення збагачених магніем ділянок $\alpha$-твердого розчину на основі алюмінію, а зрос- \\ тання волокон здійснювалося комплексом деформаційних механізмів, які діють під час надпластич- \\ ного плину сплаву.
}

Ключові слова: Алюмініевий сплав, Гомогенізація, Механізм утворення волокнистих структур, Мікронадпластичність, Надпластичність. 